\title{
Pengembangan Bahan Ajar Matematika dengan Berbasis Higher Order Thinking Skills (Hots) di Kelas VI
}

\author{
Nurul Hidayah ${ }^{1}$, Siti Rofi' $a h^{2}$ \\ 1,2,Program Studi Guru Madrasah Ibtidaiyah, Universitas Hasyim Asy'ari Tebuireng Jombang \\ e-mail: nurulhiday1997@gmail.com
}

\begin{abstract}
The main discussion of this research, among others, contains the development process that produces mathematics teaching materials based on Higher Order Thinking Skills (HOTS). Judging from the title, this research uses development research methods. The development model uses Borg and Gall which has 10 processes, including: looking for problems and potentials, collecting data, designing the products being developed, validating to experts, revising designs based on expert assessments, testing small classes, revising products based on test results. try small classes, test the product extensively, final revision, and the last process is dissemination. The results of the validation from the experts obtained a percentage of $88.8 \%$, for student assessments of small and large class trials of $86 \%$, while the value of learning outcomes between before and after using the handbook occurred an increase of $25 \%$. From the results obtained, the product developed shows that it is valid, attractive, and effectively used in the mathematics learning process in class VI.
\end{abstract}

Keywords: teaching materials, Higher Order Thinking Skills (HOTS)

\section{PENDAHULUAN}

Kualitas seseorang maupun suatu negara seringkali dinilai berdasarkan kualitas pendidikannya. Melihat fakta tersebut maka pendidikan dijadikan suatu kebutuhan yang harus benar-benar terpenuhi dalam menjalani suatu kehidupan. Sebagaimana yang tercantum dalam Undang-undang Sisdiknas No. 20 Tahun 2003 menerangkan bahwasanya pendidikan merupakan usaha sadar dan terencana untuk mewujudkan suasana belajar dalam proses pembelajaran agar peserta didik secara aktif mampu mengembangkan potensi yang ada pada dirinya untuk memiliki kekuatan spiritual keagamaan, pengendalian diri, kepribadian, kecerdasan, akhlak mulia, serta keterampilan yang diperlukan dirinya, masyarakat berbangsa, dan bernegara (UU Sisdiknas, 2010).

Dunia pendidikan menganggap matematika sebagai salah satu mata pelajaran yang sangat penting untuk mengajarkan peserta didik dalam berpikir secara lebih sistematis, logis, kreatif hingga pada tahap pemikiran yang kritis. Beberapa tujuan pembelajaran yang juga menjadikan matematika sebagai mata pelajaran yang wajib dipelajari dari mulai El-Ibtidaiy: Journal of Primary Education, Vol. 4, No. 1, April 2021, Hal 120-126 
sekolah dasar hingga sekolah menengah atas diantaranya: 1) menumbuhkan keterampilan berhitung, 2) melalui kegiatan matematika menumbuhkan kemampuan dasar untuk bekal pada tingkat selanjutnya, 3) dan dengan belajar matematika diharapkan untuk memiliki sikap yang disiplin, kreatif, cermat, 4) serta memiliki pemikiran yang logis dan kritis (Nyimas Aisyah, 2007: 23).

Namun pada kondisi yang nyata sebagian besar peserta didik merasa bahwa matematika merupakan suatu hal yang sulit dan menakutkan karena terlalu banyak rumus dalam penyelesaiannya terlebih pada soal yang menggunakan kegiatan berpikir tingkat tinggi. Pada kurikulum 2013 ini pendidikan dengan program peningkatan kompetensi pembelajaran berorientasi pada keterampilan berpikir tingkat tinggi atau dikenal dengan istilah Higher Order Thinking Skills (HOTS). Menurut King HOTS didefinisikan sebagai suatu kemampuan berpikir yang mengajarkan untuk berpikir lebih kompleks dengan tujuan mengajarkan siswa dalam berpikir secara kritis dalam menganalisis suatu permasalahan dan menarik kesimpulan. Hal tersebut menjadikan siswa khususnya tingkat sekolah dasar merasa kesulitan dalam mengerjakan soal matematika yang berbasis HOTS sehingga berpengaruh pada penurunan hasil belajar siswa (Kemendikbud, 2018: 6). Berdasarkan hasil observasi diperoleh hasil bahwa pada tahun 2019 di MI Islamiyah Kauman terjadi penurunan nilai Ujian Sekolah Berstandart Nasional (USBN) pada mata pelajaran matematika. Sebanyak 92\% siswa memperoleh nilai dibawah 55, dan kegagalan terbesar sebagian siswa pada penyelesaian soal yang berorientasi HOTS.

Guru merupakan sosok yang paling penting dalam suatu proses pembelajaran. Melihat pernyataan tersebut maka hendaklah guru mampu mencapai tujuan pembelajaran yang diharapkan dengan menciptakan suasana pembelajaran yang menyenangkan serta mampu meningkatkan motivasi belajar siswa. Depdiknas mendefinisikan seperangkat materi atau bahan belajar yang tersusun secara sistematis disebut bahan ajar. Bahan ajar yang disusun memiliki tujuan membantu guru dalam menyampaikan suatu pembelajaran (Depdiknas, 2008: 6). Beberapa jenis bahan ajar yang dapat digunakan oleh guru antara lain bahan ajar yang sifatnya pandang, dengar, maupun yang sifatnya multimedia pandang dan dengar (Sofan Amri, 2014: 161). Namun seorang guru dalam memilih suatu bahan ajar harus memperhatikan gaya belajar peserta didik sehingga siswa mampu memahami dengan baik sesuai dengan gaya belajar yang dimiliki. Selain gaya belajar, dalam memilih bahan bahan ajar juga harus menyesuaikan dengan usia peserta didik dengan tujuan agar peserta didik mampu memahami materi yang disampaikan dengan mudah sesuai dengan perkembangan kognitifnya.

Tahap operasional konkrit merupakan tahapan berpikir pada peserta didik usia sekolah dasar. Pada tahap ini anak mulai dapat berpikir lebih rasional dan mulai memperoleh tambahan kemampuan yang dapat mengkoordinasikan pemikiran serta ide yang dimilikinya dengan peristiwa tertentu ke dalam pemikirannya sendiri sehingga mampu mengambil keputusan secara logis (Udin Winataputra, 2014: 43). Melihat hal tersebut alangkah baiknya seorang guru sekolah dasar untuk menggunakan bahan ajar yang sesuai dengan perkembangan kognitif siswa dengan tujuan agar memudahkan siswa memahami suatu materi. 
Matematika merupakan suatu mata pelajaran yang bersifat abstrak sehingga bahan ajar sangatlah dibutuhkan dalam proses pembelajaran agar mampu mengubahnya menjadi hal konkrit. Hal tersebut menjadikan pentingnya melakukan suatu pengembangan bahan ajar yang sesuai dengan kebutuhan peserta didik. Beberapa penelitian pengembangan bahan ajar matematika di sekolah dasar antara lain pada tahun 2018, Suyud Riyadi Haidar melakukan penelitian pengembangan buku ajar berorientasi dengan cerita fabel dengan tujuan untuk memperkuat karakter siswa dengan menggunakan model Problem Base Learning (Suyud Riyadi, 2018). Ditahun yang sama Annur Sulistyowati juga melakukan pengembangan buku ajar yang berupa buku saku yang dikhususkan pada materi geometri dan aritmatika untuk SD/MI (Annur Sulistyowati, 2018). Hasil dari penelitian yang telah dilakukan oleh Suyud dan Annur tersebut berupa produk buku ajar yang telah tervalidasi dan mampu meningkatkan hasil belajar siswa.

Hal-hal diatas menjadikan latar belakang peneliti fokus pada pengembangan bahan ajar matematika yang berorientasi pada pemikiran tinggi atau Higher Order Thinking Skills (HOTS). Tujuan dari penelitian ini adalah menghasilkan ajar yang memiliki kualitas valid, menarik, dan efektif.

\section{METODOLOGI}

Penelitian ini menggunakan metodel penelitian R\&D yang didefinisikan sebagai suatu metode yang digunakan pada suatu penelitian untuk mendapatkan suatu produk. Penelitian yang bersifat analisis kebutuhan difungsikan secara optimal dengan tujuan dapat terciptnya produk tertentu (Sugiyono, 2017: 297). Dalam penelitian ini model pengembangan yang digunakan menurut Borg and Gall yang terbagi dalam 10 tahapan antara lain dimulai dari pencarian masalah hingga menemukan potensi, kemudian dilakukan pengumpulan data yang dilanjutkan dengan mendesain produk, setelah dilakukan desain produk dilakukan validasi desain dan revisi desain, setelah validasi dan revisi desain dilakukan uji coba produk dari kelas kecil hingga kelas besar, kemudian dilakukan revisi produk setelah uji coba, serta untuk akhir pengembangan dilakukan desiminasi.

Penelitian ini dilakukan di MI Islamiyah Kauman Ngoro yang beralamat di Jln. Arjuna No. 4D Dusun Kauman Desa Ngoro Kabupaten Jombang. Adapun data kualitatif dan kuantitatif merupakan data yang akan diolah dalam penelitian ini. Data kuantitatif dalam penelitian ini adalah data yang berisi validitas produk dari proses validasi para ahli dan responden yang diberikan siswa, sedangkan data kualitatif dalam penelitian ini adalah berupa tanggapan dan saran dari validator ahli serta berdasarkan tanggapan responden mengenai kemenarikan produk yang disajikan secara deskriptif. Dalam penelitian ini teknik pengumpulan data yang digunakan adalah menggunakan metode tes dan non tes. Metode tes yang digunakan dalam penelitian ini yaitu berupa soal pretest dan postest untuk menguji efektivitas produk, sedangkan angket validasi untuk menguji kevalidan produk yang dikembangkan merupakan teknik non tes pada penelitian ini. 


\section{HASIL DAN PEMBAHASAN}

\section{Hasil Penelitian}

Dalam langkah pengembangan model bahan ajar yang berbasis HOTS untuk siswa kelas VI, peneliti melakukan langkah-langkah sesuai dengan model pengembangan Borg and Gall yang terdiri dari 10 tahapan antara lain:

Penentuan Masalah dan Potensi, tahapan pertama pada pengembangan yaitu melakukan identifikasi masalah. Pada penelitian ini identifikasi masalah dilakukan dengan teknik observasi dan wawancara dengan guru di kelas VI tentang suatu permasalahan yang terjadi di sekolah maupun permasalahan yang terjadi di dalam kelas. Dari hasil observasi dan wawancara yang telah dilakukab peeliti diperoleh ditemui permasalahan yang mendasar pada peserta didik di kelas VI yaitu rendahnya nilai matematika siswa dalam mengerjakan soal yang berbasis HOTS. Dari permasalahan tersebut mampu memberikan potensi bagi peneliti untuk mengembangkan produk bahan ajar matematika yang berbasis HOTS untuk memudahkan siswa dalam menyesaikan soal berbasis HOTS sehingga mampu meningkatkan nilai hasil belajar siswa.

Mengumpulkan Informasi, setelah dilakukan observasi dan wawancara untuk menemukan masalah yang paling mendasar langkah selanjutnya yaitu mengumpulkan informasi. Dalam penelitian ini peneliti mengumpulkan informasi dari berbagai sumber sebagai bahan dalam menyusun produk bahan ajar matematika berbasis HOTS yang akan dikembangkan. Mendesain Produk yang dikembangkan, setelah dilakukannya tahapan pencarian potensi dan masalah serta pengumpulan data maka tahap selanjutnya adalah tahap mendesain produk. Adapun desain produk awal dalam pengembangan produk bahan ajar matematika yang berbasis HOTS terdiri dari:

Cover, pada bagian cover terdiri dari judul produk yang dikembangkan. Adapun judul yang dipilih oleh peneliti adalah Handbook Rumus Pintar Matematika Berbasis HOTS. Untuk meningkatkan motivasi siswa peneliti mendesain cover semenarik mungkin. Kata Pengantar, dalam produk bahan ajar matematika berbasis HOTS yang dikembangkan terdapat kata pengantar yang berisi ucapan puji syukur, tujuan, penjelasan, hingga harapan dikembangkannya produk bahan ajar matematika berbasis HOTS. Daftar Isi, pada produk yang dikembangkan, daftar isi berisi daftar bab dan sub bab yang akan dibahas pada isi produk bahan ajar matematika berbasis HOTS yang dikembangkan agar pembaca lebih mudah menemukan pokok bahasan yang ingin dipelajari.

Bagian Isi, pada bagian isi terdapat beberapa hal antara lain: Kompetensi dasar (KD) \& Indikator, materi, contoh soal dan pembahasan, rangkuman, dan beberapa soal latihan. Adapun HOTS pada bahan ajar yang dikembangkan terletak pada contoh soal dan pembahasan. Pembahasan pada bahan ajar berbasis HOTS akan diuraikan secara runtut dan sistematis, sedangkan soal-soal yang dipilih pada latihan soal juga akan diorientasikan HOTS sehingga diharapkan siswa lebih mudah dalam mengerjakan soal berbasis HOTS dan dapat meningkatkan hasil belajar siswa. Daftar Pustaka, pada bagian daftar pustaka berisi sumber referensi sebagai penguat dan sebagai bukti bahwa produk bahan ajar matematika berbasis HOTS yang dikembangkan memiliki dasar pemikiran.

E1-Ibtidaiy: Journal of Primary Education, Vol. 4, No. 1, April 2021, Hal 120-126 
Validasi Desain, setelah proses pengembangan bahan ajar telah didesain dan disusun maka selanjutnya melakukan validasi desain. Kegiatan validasi desain ini peneliti memilih beberapa validator diantaranya ahli materi matematika, ahli media pembelajaran, ahli desain media pembelajaran, ahli bahasa, dan ahli pembelajaran untuk menilai atau menvalidasi hasil produk yang dikembangkan. Diperoleh presentase sebesar 88,8\% dari hasil validasi yang berada pada kriteria sangat valid sehingga produk bahan ajar berbasis HOTS yang dikembangkan layak digunakan pada proses pembelajaran.

Melakukan Revisi setelah Validasi Desain, setelah dilakukannya validasi desain maka perlu dilakukannya revisi untuk menyempurnakan bahan ajar yang dikembangkan. Adapun hal yang menjadi kunci dalam melakukan revisi antara lain berdasarkan pada penilaian para ahli, tanggapan, serta saran. Menguji Coba Produk yang dikembangkan, produk yang telah divalidasi dan direvisi berdasarkan penilaian para validator ahli selanjutnya akan diuji cobakan pada kelompok kecil terlebih dahulu yaitu 20\% dari jumlah keseluruhan siswa untuk mengukur tingkat kemenarikan dari produk yang dikembangkan. Dari hasil uji coba pada kelompok kecil yang telah dilakukan diperoleh hasil presentase sebesar $86 \%$ yang berada pada kriteria sangat menarik sehingga mampu meningkatkan minat belajar siswa.

Melakukan Revisi setelah Uji Coba Kelompok Kecil, perlu dilakukannya revisi setelah uji coba produk pada kelompok kecil agar lebih sesuai dengan kriteria yang diminati oleh sebagian siswa. Revisi pada tahap ini juga dilakukan berdasarkan suatu penilaian, tanggapan, dan saran yang diberika oleh peserta didik ketika uji coba produk.

Menguji Coba Produk secara Luas, uji coba ini dilakukan sama halnya dengan menguji coba produk pada kelompok kecil namun pada tahap uji coba ini dilakukan secara lebih luas atau kelompok besar yaitu dilakukan pada seluruh siswa kelas VI di MI Islamiyah Kauman Ngoro Jombang untuk mengukur tingkat kemenarikan dan efektivitas produk yang dikembangkan. Hasil uji coba diperoleh presentase kemenarikan sebesar 86\%, sedangkan efektifitas diperoleh hasi pretest dengan rata-rata sebesar $65 \%$ dan hasil posttest dengan rata-rata sebesar 90\% sehingga terjadi kenaikan hasil belajar ketika digunakannya bahan ajar berbasis HOTS pada proses pembelajaran sebesar $25 \%$ sehingga produk bahan ajar matematika berbasis HOTS dikatakan efektif dan dapat digunakan pada proses pembelajaran.

Revisi Produk, untuk mendapatkan hasil produk yang sempurna maka perlu dilakukan revisi akhir berdasarkan penilaian keseluruhan. Desiminasi, tahapan akhir penelitian ini adalah desiminasi adapun bahan ajar berbasis HOTS yang dikembangkan akan digunakan pada proses pembelajaran matematika di kelas VI.

Setelah dilakukan pengembangan dengan model pengembangan Borg and Gall maka produk akhir yang dihasilkan dari penelitian ini adalah terselesaikannya suatu produk jadi berupa komponen pembelajaran matematika yaitu sebuah bahan ajar yang berbasis HOTS dengan judul "Handbook Rumus Pintar Matematika Berbasis HOTS" yang telah memenuhi tingkat kevalidan, kemenarikan, dan keefektifan yang menjadikan produk tersebut sangat layak apabila digunakan pada proses pembelajaran berlangsung. Adapun harapan dikembangkannya produk bahan ajar berbasis HOTS tersebut adalah agar siswa

E1-Ibtidaiy: Journal of Primary Education, Vol. 4, No. 1, April 2021, Hal 120-126 
lebih mudah menyelesaikan soal-soal yang berbasis HOTS sehingga hasil belajar yang diperoleh siswa juga meningkat.

\section{KESIMPULAN}

\section{Simpulan}

Berdasarkan penelitian yang telah dilakukan, peneliti dapat menarik kesimpulan bahwa proses pengembangan bahan ajar yang dilakukan oleh peneliti menggunakan model pengembangan Borg and Gall yang terdiri dari 10 proses antara lain: 1) mencari masalah hingga menemukan potensi; 2) kemudian dilakukan pengumpulan informasi sebagai bahan pengembangan produk; 3) setelah informasi terkumpul dilakukan proses mendesain produk yang dikembangkan; 4) apabila proses desain telah selesai maka selanjutnya dilakukan validasi desain oleh para validator ahli. Diperoleh hasil sebesar $88,8 \%$ pada proses validasi ini menunjukkan produk memiliki kriteria sangat valid; 5) melakukan revisi desain berdasarkan para validator ahli setelah dilakukan validasi desain; 6) menguji coba produk pada kelompok kecil untuk mengetahui tingkat kemenarikan. Hasil sebesar $86 \%$ pada proses ini menunjukkan bahwa produk yang dikembangkan sangat menarik; 7) setelah menguji coba pada kelompok kecil dilakukan revisi berdasarkan penilaian, tanggapan, dan saran dari responden uji coba; 8) menguji coba secara lebih luas dilakukan pada seluruh peserta didik kelas VI di MI Islamiyah Kauman Ngoro Jombang untuk mengukur tingkat kemenarikan dan efektivitas produk. Hasil sebesar $86 \%$ untuk tingkat kemenarikan dan sebesar 25\% kenaikan hasil belajar menunjukkan bahwa produk yang dikembangkan sangat menarik dan efektif; 9) kemudian dilakukan revisi akhir untuk menyempurnakan produk yang dikembangkan; 10) dan proses akhir dari pengembangan produk yaitu desiminasi produk dengan judul "Handbook Rumus Pintar Matematika Berbasis HOTS" yang akan digunakan pada proses pembelajaran berlangsung di kelas VI.

\section{REFERENSI}

Aisyah, Nyimas. (2007). Pengembangan Pembelajaran Matematika SD. Jakarta: Dirjen Dikti Depdiknas.

Amri, Sofan. (2014). Konstruksi Pengembangan Pembelajaran. Jakarta: Prestasi Pestakarya.

Annur Sulistyowati. (2018). Pengembangan Buku Saku Mata Pelajaran Matematika Materi Geometri dan Aritmatika SD/MI. Lampung: UIN Raden Intan Lampung.

Departemen Pendidikan Nasional. (2008). Pengembangan Bahan Ajar. Jakarta: Direktorat Jenderal Manajemen Pendidikan Dasar dan Menengah.

Kementrian Pendidikan dan Kebudayaan. (2018). Buku Pegangan Pembelajaran Berorientasi Keterampilan Berpikir Tingkat Tinggi. Jakarta: Direktorat Jenderal Guru dan Tenaga Kependidikan. 
Sekretaris Jenderal Pendidikan Nasional. (2010). Undang-undang No.2 Tahun 2003 tentang Sistem Pendidikan Nasional. Bandung: Citra Umbara 2.

Sugiyono, (2017). Metode Penelitian Kuantitatif, Kualitatif, dan R\&D. Bandung: Alfabeta.

Suyud Riyadi Haidar. (2018). Pengembangan Buku Ajar Matematika melalui Cerita Fabel untuk Memperkuat Karakter Siswa Menggunakan Problem Based Learning Kelas IV Sekolah Dasar. Bandar Lampung: Universitas Lampung.

Udin S, Wiranataputra. (2014). Teori Belajar dan Pembelajaran. Tangerang Selatan: Universitas Terbuka. 